\title{
Akupunktur sebagai Terapi De Quervain's Tenosynovitis
}

\author{
Sri Wahdini, ${ }^{12^{*}}$ Christina Simadibrata ${ }^{3}$
}

\begin{abstract}
De Quervain's tenosynovitis is a disease with pain and edema in the styloid process due to thickening of the sheaths that encase the tendons of abductor pollicis longus (APL) and extensor pollicis brevis (EPB). Management of De Quervain's tenosynovitis include pharmacotherapy combined with conservative therapy and if it fails then surgical intervention is required. In case of De Quervain's tenosynovitis, acupuncture for relieving pain and stiffness. Reported the case of a woman aged 52 year, complaints of pain and stiffness in the left thumb since two months before went to the Poliklinik Akupunktur dr. Cipto Mangunkusumo Nasional Hospital. On physical examination the left wrist area found tenderness and spasm in the area of APL and EPB, VAS 4, there was limitation in the first carpometacarpal joint functional and Finkelstein's test was positive. Acupuncture therapy done at the point LI5, LU7, LU9 and Ashi. There was pain reduction and functional improvement of the carpometacarpal joints. Acupuncture gives good results for pain and stiffness in patients with de Quervain's.
\end{abstract}

Keywords: abductor pollicis longus, acupuncture, De Quervain’s, extensor pollicis brevis, Finkelstein’s test,

De Quervain's tenosynovitis merupakan kondisi peradangan selaput tendon yang menyelubungi otot abduktor polisis longus (APL) dan ekstensor polisis brevis (EPB) sehingga menjepit kedua tendon tersebut. Kedua otot tersebut berfungsi mengontrol gerakan dan menjaga stabilitas sendi ibu jari. Sindroma ini juga dikenal sebagai washerwoman's sprain, Radial styloid tenosynovitis, de Quervain disease, de Quervain's tenosynovitis, de Quervain's stenosing tenosynovitis atau mother's wrist. ${ }^{1}$

\footnotetext{
* Penulis untuk korespondensi : Email :sri.wahdini01@ui.ac.id

1 Departemen Parasitologi, Fakultas Kedokteran Universitas Indonesia

2 Rumah Sakit Universitas Indonesia

3 Program Studi Spesialis Akupunktur Medik, Fakultas Kedokteran Universitas Indonesia-

Departemen Medik Akupunktur RSUPN dr. Cipto Mangunkusumo
}

Kelainan ini sering ditemukan pada perempuan dibandingkan dengan pria dengan rasio kejadian mencapai 6:1 dan terutama usia 40-50an. ${ }^{2} \mathrm{Hal}$ ini dikarenakan wanita mempunyai prosessus styloideus yang lebih besar daripada laki-laki. De Quervain's tenosynovitis dapat terjadi selama kehamilan atau selama periode postpartum. ${ }^{3}$ Faktor risiko de Quervain tenosynovitis antara lain akibat penggunaan sendi yang repetitif atau berlebihan (overuse) terutama sendi karpometakarpal (CMC) ibu jari seperti untuk kegiatan menggendong anak atau memeras pakaian. ${ }^{4}$ Faktor risiko lainnya adalah trauma yang mengenai tendon APL dan EBP, penderita rheumatoid arthritis dan diabetes mellitus. ${ }^{1,5}$

Tatalaksana De Quervain's tenosynovitis meliputi farmakoterapi dikombinasi dengan terapi konservatif dan apabila gagal maka diperlukan intervensi bedah. Farmakoterapi yang diberikan berupa analgetik oral atau injeksi dan kortikosteroid injeksi. Terapi konservatif bertujuan mengurangi rasa nyeri dan mencegah perburukan 
gejala. Pasien dianjurkan untuk mengistirahatkan (immobilisasi) kompartemen dorsal pertama ibu jari, menghindari pekerjaan yang menggunakan pergelangan tangan atau ibu jari hingga tercapai pengobatan yang adekuat. Idealnya, immobilisasi dilakukan selama 4-6 minggu. Selain itu dapat diberikan terapi konservatif berupa fisioterapi dan akupunktur. ${ }^{6}$ Intervensi bedah diperlukan jika terapi konservatif tidak efektif lagi terutama pada kasuskasus lanjut yang telah terjadi perlengketan pada tendon sheath. ${ }^{1,7}$

Akupunktur telah banyak digunakan sebagai terapi utama atau tambahan untuk kelainan muskuloskeletal. Akupunktur tidak hanya dapat mengurangi nyeri tetapi juga meningkatkan status fungsional pasien. Penelitian Hadianfard et $\mathrm{al}^{8}$ yang membandingkan efikasi akupunktur dengan injeksi metilprednisolon asetat di kompartemen dorsal pertama pergelangan tangan untuk penanganan $D e$ Quervain's tenosynovitis, didapatkan penurunan visual analogue scale (VAS) dan peningkatan fungsional pada kelompok akupunktur yang lebih baik dibandingkan dengan kelompok injeksi steroid.. Wolkenstein $^{9}$ melakukan evaluasi manfaat terapi akupunktur untuk epikondilitis lateral kronis. Sebanyak 23 pasien diberikan real akupunktur dan 22 pasien menerima sham akupunktur sebanyak 10 kali terapi, 2 kali seminggu. Terdapat perbedaan yang bermakna pada kekuatan otot, intensitas nyeri dan skala disabilitas pada kelompok real akupunktur dibandingkan dengan sham akupunktur pada penilaian 2 minggu setelah terapi. Sedangkan pada penilaian 2 bulan setelah terapi kelompok akupunktur masih lebih baik daripada kelompok sham akupunktur walaupun secara statistik tidak bermakna. ${ }^{9}$ Akupunktur sebagai terapi De Quervain's tenosynovitis dilakukan dengan memilih titik local di sekitar daerah tendon dan otot EPB dan APL dengan tujuan utama untuk menghilangkan nyeri dan kekakuan. ${ }^{10}$ Laporan kasus ini bertujuan memaparkan manfaat akupunktur sebagai pilihan terapi De Quervain's tenosynovitis.

\section{Laporan Kasus}

Ny E, usia 55 tahun dirujuk ke Poliklinik Akupunktur Medik dari Poliklinik Bedah Rumah Sakit Umum Pusat Nasional Dr. Cipto Mangunkusumo dengan keluhan nyeri pada ibu jari kiri sejak 2 bulan yang lalu. Rasa nyeri dirasakan hanya sampai pergelangan tangan dan nyeri bertambah apabila ibu jari di tekuk serta terkadang pasien tidak mampu memegang/menggenggam suatu barang seperti gelas. Rasa nyeri timbul perlahan dan semakin berat. Bengkak, kemerahan dan mati rasa (baal) disangkal. Tidak ada keluhan yang sama pada ibu jari dan pergelangan tangan kanan. Tidak ada riwayat trauma. Rasa kaku yang timbul pada jarijari lain terutama pagi hari, hipertensi, dan diabetes melitus disangkal. Pasien menopause sejak empat tahun yang lalu. Pasien adalah ibu rumah tangga yang sehari-hari mengerjakan pekerjaan rutin seperti membersihkan rumah, mencuci dan memasak. Pasien direncanakan untuk operasi, akan tetapi pasien menolak karena takut dan ingin mencoba terapi non bedah.

Pemeriksaan fisik didapatkan pasien tampak sakit ringan, kesadaran compos mentis, tekanan darah $117 / 74 \mathrm{mmHg}$, frekuensi nadi 75x/menit, frekuensi napas 18x/menit, suhu afebris, VAS 4. Status generalis dalam batas normal. Status lokalis sendi CMC I (ibu jari) 


\begin{tabular}{|c|c|c|}
\hline & Kanan & Kiri \\
\hline Look : & $\begin{array}{l}\text { tidak terdapat deformitas, tidak } \\
\text { terdapat atrofi otot, tidak ada } \\
\text { kemerahan }\end{array}$ & $\begin{array}{l}\text { tidak terdapat deformitas, tidak } \\
\text { terdapat atrofi otot, tidak ada } \\
\text { kemerahan }\end{array}$ \\
\hline Feel : & $\begin{array}{l}\text { suhu normal, tidak terdapat } \\
\text { edema, tidak terdapat nyeri tekan } \\
\text { dan spasme pada daerah APL } \\
\text { dan EPB }\end{array}$ & $\begin{array}{l}\text { suhu normal, tidak terdapat } \\
\text { edema, nyeri tekan dan spasme } \\
\text { pada daerah APL dan EPB }\end{array}$ \\
\hline \multicolumn{3}{|l|}{$\begin{array}{l}\text { Move } \\
\text { (gerakan menggenggam) }\end{array}$} \\
\hline $\begin{array}{l}\text { Power grip (menggenggam } \\
\text { tabung) }\end{array}$ & Dapat dilakukan & Tidak mampu \\
\hline $\begin{array}{l}\text { Ball grip (menggenggam } \\
\text { bola) }\end{array}$ & Dapat dilakukan & Tidak mampu \\
\hline $\begin{array}{l}\text { Pinch grip (mengambil } \\
\text { barang yang tipis) }\end{array}$ & Dapat dilakukan & Tidak kesulitan \\
\hline $\begin{array}{l}\text { Three point grip (memegang } \\
\text { pensil) }\end{array}$ & Dapat dilakukan & Sangat Sulit \\
\hline
\end{tabular}

Tes Finkelstein's negatif/positif, Grind Test negatif/negatif. Pemeriksaan laboratorium didapatkan Hb 13,5 g/dL, leukosit 5.340/ uL, laju endap darah $15 \mathrm{~mm}$, asam urat 3,6 mg/dL, glukosa sewaktu $92 \mathrm{mg} / \mathrm{dL}$.

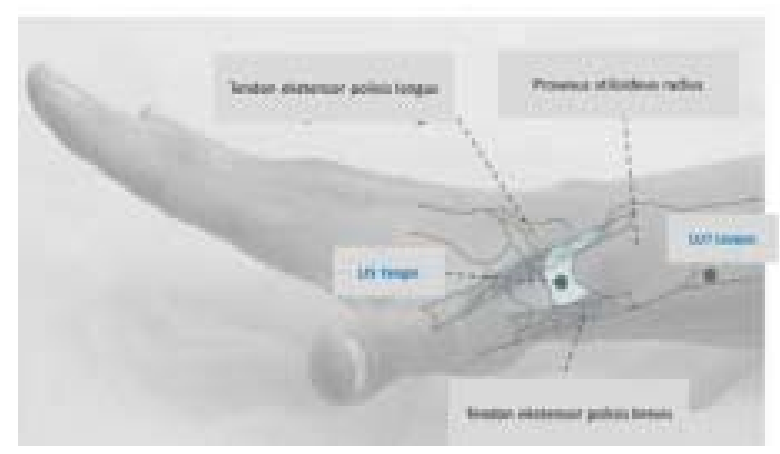

Pasien didiagnosis sebagai De Quervain's tenosynovitis sinistra. Terapi yang diberikan akupunktur manual menggunakan jarum ukuran 0,25 mm x 25 mm di titik LI5 Yangxi, LU7 Lieque, LU9 Taiyuan, (Gambar 1) dan Ahshi.

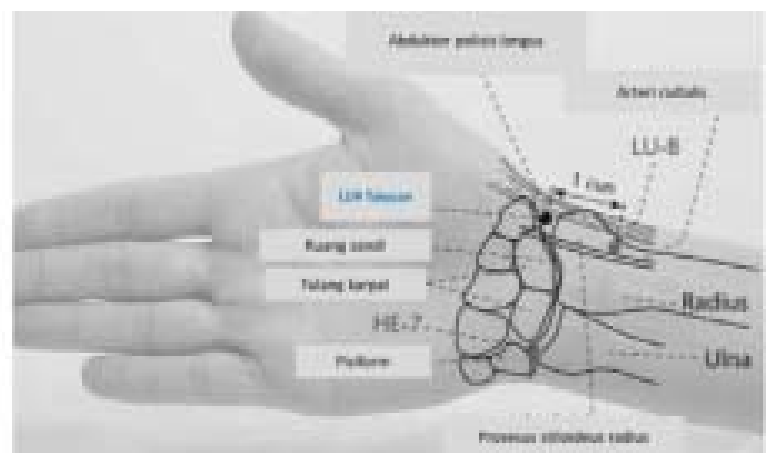

Gambar 1. Lokasi Titik LI 5, LI 7, dan LU $9^{11}$

Terapi diberikan sebanyak satu seri atau $12 \mathrm{kali}$ terapi dengan frekuensi 2-3x/minggu dan setiap sesi selama 30 menit. Pasien dianjurkan untuk menghindari gerakan berlebihan pada ibu jari dan pergelangan tangan, seperti menggunting, menjahit, mengulek, mengucek pakaian; menggunakan thum spica untuk mengistirahatkan ibu jari; memberikan kompres dingin untuk mengurangi edema. Kemajuan selama terapi dapat dilihat di Tabel 1. Perubahan dirasakan pasien setelah sesi terapi ke-4 dan sejak sesi terapi ke-6 sampai ke-12 terapi akupunktur manual ditambah dengan rangsang listrik (elektroakupunktur) 
Tabel 1. Pemeriksaan Status Lokalis Sendi CMC I Sinistra di Setiap Sesi Terapi

\begin{tabular}{|c|c|}
\hline $\begin{array}{c}\text { Sesi } \\
\text { Terapi }\end{array}$ & Keluhan dan Hasil Pemeriksaan \\
\hline II & $\begin{array}{l}\text { Nyeri berkurang setelah terapi tetapi kembali lagi keesokan harinya, VAS } 4 . \\
\text { Power grip: tidak mampu; Ball grip: tidak mampu; Three point grip: sangat sulit. }\end{array}$ \\
\hline III & $\begin{array}{l}\text { Nyeri pada ibu jari dan pergelangan tangan mulai berkurang dan timbul } 2 \text { hari setelah } \\
\text { kunjungan terakhir, VAS } 3 \text {. } \\
\text { Power grip: tidak mampu; Ball grip : tidak mampu; Three point grip: sangat sulit. }\end{array}$ \\
\hline IV & $\begin{array}{l}\text { Nyeri pada ibu jari dan pergelagan tangan berkurang, VAS } 3 \text {. } \\
\text { Power grip: sangat sulit; Ball grip: sangat sulit; Three point grip: sedikit sulit. }\end{array}$ \\
\hline V & $\begin{array}{l}\text { Nyeri pada ibu jari, tetapi nyeri pada pergelangan tangan sudah hilang, VAS } 2 . \\
\text { Power grip: sangat sulit; Ball grip: sangat sulit; Three point grip: sedikit sulit. }\end{array}$ \\
\hline VI & $\begin{array}{l}\text { Nyeri pada ibu jari terutama jika ditekuk, tetapi nyeri pada pergelangan tangan sudah } \\
\text { hilang, VAS } 2 \text {. } \\
\text { Power grip: sulit; Ball grip: sulit; Three point grip: sedikit sulit. } \\
\text { Terapi diganti menjadi elektroakupunktur (EA) gelombang kontinu, frekeunsi } 2 \mathrm{~Hz} \text {. }\end{array}$ \\
\hline VII & $\begin{array}{l}\text { Nyeri pada ibu jari berkurang dan pasien sudah mulai mampu menggenggam } \\
\text { barang,VAS } 2 \text {. } \\
\text { Power grip: sulit; Ball grip: sulit; Three point grip: sedikit sulit. }\end{array}$ \\
\hline VIII & $\begin{array}{l}\text { Rasa nyeri pada ibu jari hanya timbul jika banyak beraktifitas,VAS } 1 . \\
\text { Power grip: sulit; Ball grip: sulit; Three point grip: sedikit sulit. }\end{array}$ \\
\hline $\begin{array}{l}\text { IX dan } \\
\quad X\end{array}$ & $\begin{array}{l}\text { Rasa nyeri pada ibu jari hanya timbul jika banyak beraktifitas, VAS } 1 . \\
\text { Power grip: sulit; Ball grip: tidak kesulitan; Three point grip: tidak kesulitan. }\end{array}$ \\
\hline $\begin{array}{l}\text { XI dan } \\
\text { XII }\end{array}$ & $\begin{array}{l}\text { Rasa nyeri pada ibu jari hilang pasien sudah bisa beraktivitas mengerjakan pekerjaan } \\
\text { rumah seperti dahulu, VAS } 0 \text {. } \\
\text { Power grip:sedikit sulit; Ball grip: tidak kesulitan; Three point grip: tidak kesulitan. }\end{array}$ \\
\hline
\end{tabular}

\section{Pembahasan}

Diagnosis de quervain tenosynovitis pada pasien ini ditegakkan berdasarkan keluhan nyeri ibu jari, terdapat riwayat melakukan pekerjaan sebagai ibu rumah tangga yang memerlukan aktivitas berulang di pergelangan tangan dan ibu jari. Pada pemeriksaan fisik tidak didapatkan deformitas atau tanda radang, didapatkan nyeri dan spasme pada daerah APL dan EPB, keterbatasan melakukan gerakan power grip dan ball grip. Selanjutnya dilanjutkan dengan tes khusus untuk memperkuat diagnosa yaitu finkelstein's test. Pasien diminta mengepalkan tangannya selama 30 detik dimana ibu jari diliputi oleh jari-jari lainnya selanjutnya dilakukan ulnar deviasi plus ekstensi, pemeriksaan dinyatakan positif apabila timbul nyeri karena dalam posisi tersebut tekanan ibu jari meningkat. ${ }^{12,13}$

Masalah yang paling utama pada pasien ini adalah nyeri dan kekakuan ibu jari sampai ke pergelangan tangan sehingga pasien tidak dapat melakukan aktivitas sehari-hari sebagai ibu rumah tangga seperti memasak, mengulek, dan menggenggam barang tertentu. Spasme terjadi sebagai bagian dari proteksi agar bagian tubuh yang nyeri tidak bergerak sehingga tidak menimbulkan kerusakan jaringan lebih parah. Spasme bersifat 
sementara dan dapat kembali normal. De Quervain Tenosynovitis menimbulkan permasalahan nyeri, spasme, keterbatasan lingkup gerak sendi sehingga menyebabkan penurunan kemampuan fungsional. ${ }^{1}$ Pada pasien ini dipilih terapi akupunktur manual yang dilanjutkan dengan EA selama 30 menit persesi, sebanyak 12x terapi. Efek utama yang diharapkan dari terapi akupunktur pada De Quervain Tenosynovitis adalah analgesia dan kelenturan jaringan ikat tendon yang memungkinkan pasien untuk menggerakkan sendi pergelangan tangan dan ibu jari sehingga dapat beraktivitas kembali pekerjaan seharihari. ${ }^{6}$ Terapi akupunktur merangsang serabut Aâ dan memodulasi nucleus rafe magnus (NRM) melalui berbagai mediator untuk menghasilkan analgesi. ${ }^{14}$ Pemilihan titik LI5 Yangxi, LU7 Lieque, LU9 Taiyuan secara evidence based digunakan untuk kelainan pada lengan bawah dan pergelangan tangan..$^{8,9,11}$ Titik LU9 terletak pada tepi tendon APL, LU7 terletak antara otot brachioradialis dan APL sedangkan LI5 terletak dekat dengan tendon EPB. ${ }^{11}$

Pada terapi VI sampai XII ditambahkan rangsangan menggunakan EA dengan tujuan meningkatkan efektivitas jarum dengan adanya stimulasi yang terus menerus. Dengan pemberian EA didapatkan efek terapi gabungan yaitu stimulasi saraf listrik transkutan (TENS) dan akupunktur manual. Selain itu dengan menggunakan EA frekuensi, tegangan, bentuk, dan panjang gelombang atau jenis stimulasi dapat distandardisasi. Efek fisiologis yang diharapkan dari EA adalah pelepasan endorfin yang lebih maksimal untuk sehingga dapat menghilangkan rasa sakit, mengurangi peradangan, meningkatkan sirkulasi darah, analgesia melalui hambatan stimulus nyeri dan relaksasi otot. Pada pasien ini dipilih gelombang kontinu, frekuensi rendah. Rangsangan akupunktur dengan frekuensi rendah (2-15 Hz) dapat melepaskan â endorfin dan enkephalin di brainstem dan hipotalamus serta endomorfin yang bekerja di reseptor ì dan ä. Akupunktur juga melepaskan cholecystokinin octapeptide (CCK-8), 5-hydroxytryptamine (5-HT), $\mathrm{N}$-methyl D-aspartat-acid (NMDA), angiotensin, somatostatin, vasopresin, dan arginin, sehingga menimbulkan efek anti-inflamasi dan analgesik. Selain melalui aktivasi sistem modulasi nyeri endogen, terapi akupunktur melalui Substansi P, Calcitonin gene-related peptide (CGRP) dan Nitrit oksida (NO) akan meningkatkan sirkulasi darah di daerah nyeri. ${ }^{14,15}$
Tendon memiliki matriks ekstraseluler yang disusun oleh serabut kolagen yang tebal dengan jumlah sel yang relatif sedikit. Matriks ekstraseluler meliputi protein fibrosa, protein penyambung dan kompleks polisakarida. Fibroblast jaringan ikat, sel epitel, sel otot dan neuron mengeluarkan substansi penyusun matriks ekstraseluler. Tendon bersifat meregang kuat karena banyak mengandung kolagen. Penusukan pada titik akupunktur akan meningkatkan migrasi fibroblast sehingga dapat meningkatkan kolagen dan asam amino seperti hidroksiprolin yang pada akhirnya dapat meningkatkan kekuatan dan kelenturan tendon. ${ }^{9,10}$ Penyembuhan akibat cedera pada pergelangan tangan dan ibu jari lebih sulit tercapai dan terkadang membutuhkan waktu lebih lama karena persendian tersebut sering digunakan dalam aktivitas kehidupan sehari-hari.

\section{SIMPULAN}

Manual akupunktur yang dilanjutkan dengan elektroakupunktur efektif mengurangi nyeri dan meningkatkan range of motion sendi karpometakarpal (CMC) ibu jari penderita de quervain tenosynovitis. Akupunktur dapat dipertimbangkan sebagai salah satu pilihan terapi $d e$ quervain tenosynovitis.

\section{DAFTAR PUSTAKA}

1. Martin A, Awan HM. De Quervain's Syndrome. In: Orthopedic surgery clerkship. Springer: Cham. 2017. p. 157-160.

2. Kaux JF, Forthomme B, Goff CL, Crielaard JM, Croisier JL. Current opinions on tendinopathy. Journal of Sports Science and Medicine. 2011;10:238-53.

3. Borg-Stein J, Dugan SA. Musculoskeletal disorders of pregnancy, delivery, and postpartum. Phys Med Rehabil Clin N Am. 2007;18:459-76.

4. Stahl S, Vida D, Meisner C, Stahl AS, Schaller HE, Held M. Work related etiology of de Quervain's tenosynovitis: a case-control study with prospectively collected data. BMC musculoskeletal disorders. 2015;16(1):126.

5. Shen PC, Chang, PC, Jou IM, Chen CH, Lee $\mathrm{FH}$, Hsieh JL. Hand tendinopathy risk factors in 
Taiwan: A population-based cohort study. Medicine. 2019;98(1) :e13795.

6. Da Silva JB, Batigalia F. Acupuncture in de quervain's disease: a treatment proposal. BMJ. 2014;32:70-2.

7. Howell ER. Conservative care of De Quervain's tenosynovitis/tendinopathy in a warehouse worker and recreational cyclist: a case report. J Can Chiropr Assoc 2012;56(2):121-7.

8. Hadianfard M, Ashraf A, Fakheri M, Nasiri A. Efficacy of acupuncture versus local methylprednisolone acetate injection in de quervain's tenosynovitis: A RCT. JAcupunct Meridian Stud 2014;7(3):115-21.

9. Wolkenstain MF, Karst M, Gehrke A. Acupuncture in chronic apicondylitis:RCT. Rheumatology.2001;41:205-9.

10. Tao Ma Y. Biomedical acupuncture for sports and trauma rehabilitation dry needling techniques. Churchill livingstone, America. 2011.
11. Focks, C. E-book-atlas of acupuncture. Elsevier Health Sciences. Edisi ke-7. London: Churchill Livingstone;2008.

12. Brunelli G. Finkelstein's versus Brunelli's test in De Quervain tenosynovitis. Chirurgie de la Main. 2003;22(1):43-4. DOI: 10.1016/s12973203(02)00005-7.

13.Wu F, Rajpura A, Sandher D. Finkelstein's Test Is Superior to Eichhoff's Test in the Investigation of de Quervain's Disease. Journal of hand and microsurgery. 2018;10(02):116-8.

14.Leung L. Neurophysiological basis of acupuncture-induced analgesia-an updated review. J Acu Meridian Studies. 2012;5(6):26170.

15.Warner DS. Mechanisms of acupunctureelectroacupuncture on persistent pain. Anesthesiology 2014;120(1):482-503. 